\title{
Population Structure of Woody Plant Species at Jello-Muktar Dry Afromontane Forest, South-Eastern Ethiopia
}

\author{
Muktar Reshad* Alemayehu Beyene \\ Oda Bultum University, College of Natural Resources and Environmental Science. Chiro, Ethiopia
}

\begin{abstract}
There is limited quantitative information with regard to the vegetation structure in South-eastern Ethiopia. This study was therefore carried out to determine the density, DBH, Basal area and height distributions of woody plant species at Jello-Muktar dry afromontane forest. Systematic sampling design was used to collect vegetation data in total of 90 circular sample plots of each $30 \mathrm{~cm}$ radius. In each plot all woody plants which are $\geq 2 \mathrm{~cm}$ diameter at breast height and height $>1 \mathrm{~m}$ were identified, measured and recorded. Analysis of Size class distribution was performed for height (100 $\mathrm{cm}$ and above) and diameter classes $(2 \mathrm{~cm}$ and above) and BA of each woody plant species with $\mathrm{DBH} \geq 2 \mathrm{~cm}$ was computed The study revealed that more than $93 \%$ of the individuals had the DBH class distribution of more than $40.01 \mathrm{~cm}$ DBH. The DBH class distribution showed an inverted J-shape curve with the presence of more individuals in the lower DBH classes which is an indication of the active regeneration. The basal area in this study ranged from $10.9 \mathrm{~m}^{2} /$ ha for DBH class 1 to $59.02 \mathrm{~m}^{2} /$ ha for DBH class 11 . The total basal area was found to be $245.65 \mathrm{~m}^{2}$ and there was a J-shape curve relationship between DBH class and basal area class distribution. About $89 \%$ of trees and shrubs had heights of more than $5 \mathrm{~m}$ tall but only $3.45 \%$ the total individuals recorded were more than $30 \mathrm{~m}$. The population structure of the entire forest showed higher stem densities in the Lower diameter classes and progressively declining stem densities with increasing Diameter classes. Study of woody plant species population structure is an invaluable strategy for planning management actions and also helps in identifying the status of the forest stand with regard to its rate of disturbance. Hence it is better to manage those parts of forest stands with less number of individuals through enrichment planting of indigenous tree species.
\end{abstract}

Keywords: DBH, basal area, height, DBH class, height class, dry afromontane, woody

DOI: $10.7176 / \mathrm{JNSR} / 13-5-03$

Publication date:March $31^{\text {st }} 2021$

\section{INTRODUCTION}

Jello-Muktar dry afromontane forest is part of the Chercher highland dry afromonate forest and is one of the forests under Participatory Management (PFM) Project in Oromia National Regional State Government. The forest provides ecosystem, socioeconomic, and cultural services that sustain local livelihoods (Muktar, 2017). JelloMuktar dry afromontane forest contributes considerably to household livelihoods by providing fuel, construction materials, grazing, medicine, food, materials of farming implements, and potentially supplementing incomes especially for poor communities ( Muktar, 2017). In Ethiopia dry afromontane forests form the largest part of the existing natural vegetation (Giday , 2013) but poorly documented in terms of its population structure.

Knowledge of the vegetation population structure of a given forest is important as climate in shaping ecosystem functioning (J.J. Gaitan et al., 2014). Such information is invaluable in management for coming up with strategies for climate change mitigation (Kalaba et al. 2012). Vegetation structure data can also be used to mobilise financial resources through C based Payments for Ecosystem Services (Ryan et al., 1997). Data with regard to floristic composition and diversity of the Jello-Muktar dry afromontane forest has been studied and documented (Muktar et al., 2019)

Against this, there is limited quantitative information with regard to the vegetation population structure in Jello-Muktar dry afromontane forest, despite the huge importance of such information. Data on vegetation structure is invaluable to forest management in designing strategies for sustainable management under different disturbance regimes (Kalaba et al., 2012). Population structure studies in tropics are almost defined in terms of the size-class or diameter distribution of individuals given the lack of well-defined growth rings and the difficulty of accurately determining tree age in the tropics (Bormann and Berlyn, 1981),.

Jello-Mukatar Dry afromtane forest is exposed to anthropogenic activities as the surrounding farming communities continue to depend on the forest for sustenance. A PFM, which involves local communities in management decisions, has recently been implemented by Oromia Forest and Wilde life Enterprise. The success of the project will depend on an understanding of the forest dynamics and especially the role of disturbance factors in shaping the forest population structure. This study was therefore aimed to determine the density, DBH, Basal area and height distributions of woody plant species at Jello-Muktar dry afromontane forest. 


\section{MATERIALS AND METHODS \\ 2.1. Description of the Study site}

The study site is situated at $8^{0} 55^{\prime} \mathrm{N}-9^{0} 05^{\prime} \mathrm{N}$ latitude and $40^{0} 50^{\prime} \mathrm{E}-40^{0} 51^{\prime} \mathrm{E}$ longitude, about $342 \mathrm{kms}$ southeast of Addis Ababa. Its altitude ranges from 1900 to over 3310masl, having subtropical climatic condition with mean annual temperature of $10^{\circ} \mathrm{C}$ and mean rainfall of $1220 \mathrm{~mm}$.

It is part of the Chercher highlands in West Hararghe Zone having numerous micro-catchments with diversified bio-physical and socio-economic environments (Murphy, 1968). Anthropogenic processes due to shifting cultivation and forest clearing has led to continuous removal of soil materials that strongly affected the microclimate and soil development of the area. The study area is dissected by streams due to their erosive processes for prolonged period of time. The sub-watershed is within Wabi-shebele and Rift Valley drainage systems, drained by Chiro Qela and Jello perennial streams towards the Rift system while perennial streams like Welenso and Ula Quni and seasonal streams like Rukele Arba Feno and Dingete draining towards Wabi Shebelle drainage system (EMA, 1999).

\subsection{Vegetation Sampling, Design and Plot Allocation}

A systematic sampling design was used to collect data on vegetation of different growth forms (Kent and Coker 1992; Mueller-Dombois and Ellenberg, 1974). Vegetation information was collected in total of 90 circular sample plots of each $30 \mathrm{~cm}$ radius. The samples were distributed along transects that ranges from $1 \mathrm{~km}$ to $1.5 \mathrm{~km}$ which were laid parallel to the slope. The distance between adjacent transects was $500 \mathrm{~m}$ while $200 \mathrm{~m}$ between consecutive plots. In each plot all woody plants which are $\geq 2 \mathrm{~cm}$ diameter at breast height (dbh at $1.3 \mathrm{~m}$ above ground) and height $>1 \mathrm{~m}$ were identified, measured and recorded. The diameter was measured using diameter tape and caliper while total height of individual trees was measured using hypsometer and marked stick (for smaller individuals).

\subsection{Data Analysis}

Density of a species was calculated as: the number of individuals of that species/area sampled.

Analysis of Size class distribution were performed for height $(100 \mathrm{~cm}$ and above) and diameter classes $(2 \mathrm{~cm}$ and above). Accordingly, Woody plants were classified in to eleven DBH size classes as: $1=2.0-10 \mathrm{~cm}, 2=10.01-$ $20.0 \mathrm{~cm}, 3=20.01-30.0 \mathrm{~cm}, 4=30.01-40.0 \mathrm{~cm}, 5=40.01-50.0 \mathrm{~cm}, 6=50.01-60.0 \mathrm{~cm}, 7=60.01-70.0 \mathrm{~cm}, 8=70.01-$ $80.0 \mathrm{~cm}, 9=80.01-90.0 \mathrm{~cm}, 10=90.01-100.0 \mathrm{~cm}$, and 11 stands for DBH class $>100.0 \mathrm{~cm}$. Similarly, analysis of the height class followed that height class as: $1=1.0-5.0 \mathrm{~m}, 2=5.01-10.0 \mathrm{~m}, 3=10.01-15.0,4=15.01-20.0,5=$ 20.01-25.0m, $6=25.01-30.0 \mathrm{~m}$ and 7 stands for height class $>30.0 \mathrm{~m}$. Size class distribution for both height and diameter at breast height ( $\mathrm{dbh}$ ) was constructed.

Basal area (BA) of each woody plant species that have $\mathrm{dbh} \geq 2 \mathrm{~cm}$ was computed using the equation based on diameter at breast height $(\mathrm{DBH})$ as: $B A=\frac{\mathrm{nD}^{2}}{\mathbf{4}}$ Where: BA is basal area, $\Pi$ is 3.14 and $\mathrm{D}$ is diameter at breast height (at $1.30 \mathrm{~m}$ ).

The analysis was performed using SPSS version 20.0 statistical software ((IBM Corporation, 2001).

\section{RESULTS AND DISCUSSION}

\subsection{Density and DBH class distribution}

There was an inverse relationship between the DBH class and the density of woody species. The number of individuals increased from 1877 stems/ha in the first class to 1938 stems/ha in the second class (Figure 1). Starting from the second class, the number of individuals highly decreased with increasing DBH class finally to 8 stems /ha in the final DBH class 11. Most of the individuals were recorded in the lower diameter class and the number is subsequently decreasing so that the higher classes are having very few individuals. The study revealed that more than $93 \%$ of the individuals had the DBH class distribution of more than $40.01 \mathrm{~cm} \mathrm{DBH}$. The first three DBH classes (DBH class1 to DBH class 3) accounted about $86.5 \%$ of the total number of individuals while the rest of DBH classes (DBH class 4 to DBH class 11 ) contributed only $13.5 \%$ of the total number of woody plant individuals. The DBH class distribution showed an inverted J-shape curve (Figure 1) with the presence of more individuals in the lower DBH classes which is an indication of the active regeneration (Demel Teketay, 1997) and/or high rate of mortality in large-sized individuals (Ahmed 2017). Such type of population structure is commonly found in many natural forests and is referred to as stable size distribution. Recent studies have questioned reliance on inverse $\mathrm{J}$ distributions in forest management as they are based on a biologically unrealistic assumption of equal mortality among size classes (J. A. Isango, 2007). Declining populations may also show the classic "inverse J" shape and some stable populations may not show this shape due to differences in growth rates among size classes (C.B.Virillo et al., 2011).

The lower number of tree density in the higher DBH class distribution might be related the previous presence 
of selective logging in the forest. This is in line with similar studies conducted at Asebot dry afromontane forest (Tura et al., 2017) and Kamtok Afromontane moist forest (Gurmessa et al., 2012). It also agreed with report of Hundera and Gadissa (2008) for Belete forest from South Western Ethiopia.

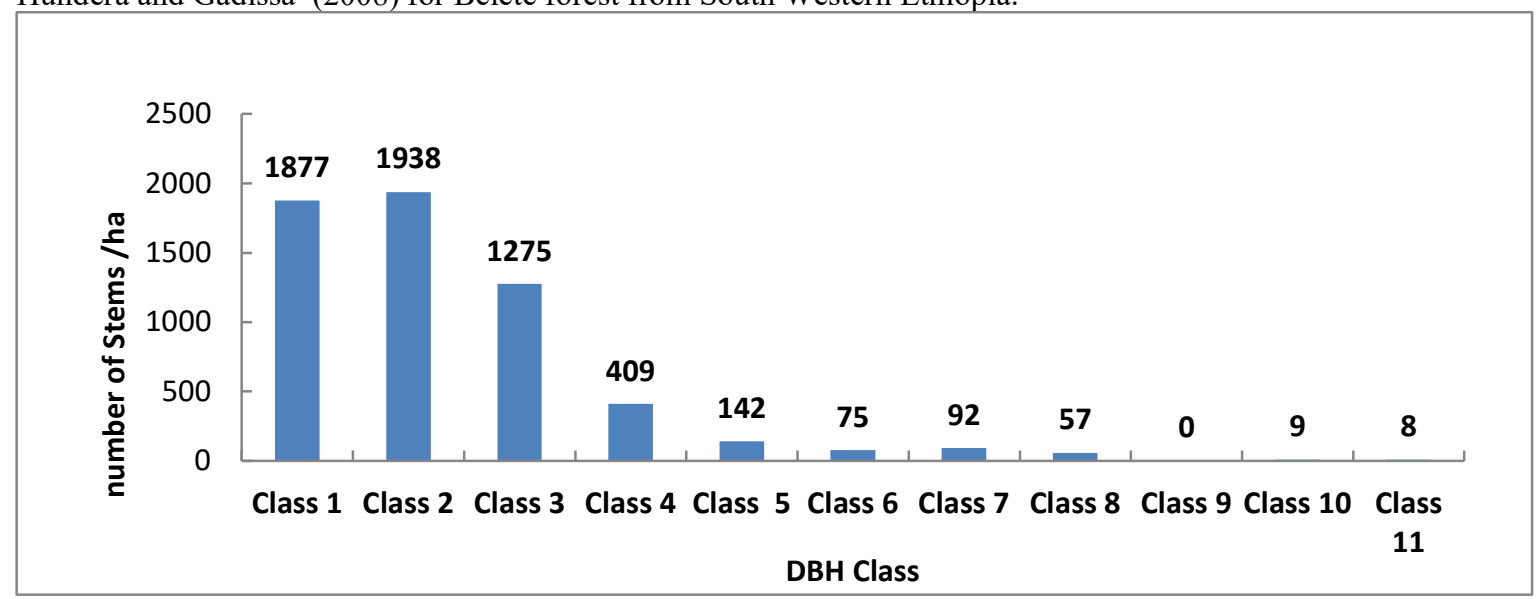

Figure 1. Density of woody plant species along DBH classes

The overall mean stem density of the Jello-Muktar dry afromontane forest was found to be 5882 trees/ha. This figure much higher than the density of trees and shrubs reported from Asebot dry afromontane forest (Tura et al., 2017). The differences in the density of the two forests could be related to the fact that the two forests are found in different agro-ecology. Jello-Muktar forest is found in highland agro-ecology while Asebot forest is located in lowland agro-ecology.

It was again higher as compared to the densities of trees and shrubs at $\mathrm{DBH}>2 \mathrm{~cm}$ reported from dry afromontane forest of Bale Mountains National park ( Haile Yineger et al. ,2008) and density reported from Miombo woodlands (Clemence and Christopher, 2016).

Variation also exists in terms of DBH among species of different types. An indigenous tree species of Podocurpus faccatus was found to have the largest DBH $\left(150 \mathrm{~m}^{2} / \mathrm{ha}\right)$, followed by Juniperus procera $\left(145 \mathrm{~m}^{2} / \mathrm{ha}\right)$, Hagenia abyssinica $\left(98 \mathrm{~m}^{2} / \mathrm{ha}\right.$ ) and Albizzia gummifera $\left(45 \mathrm{~m}^{2} / \mathrm{ha}\right.$ ) (Figure 2 ) which are all again indigenous to Ethiopia.

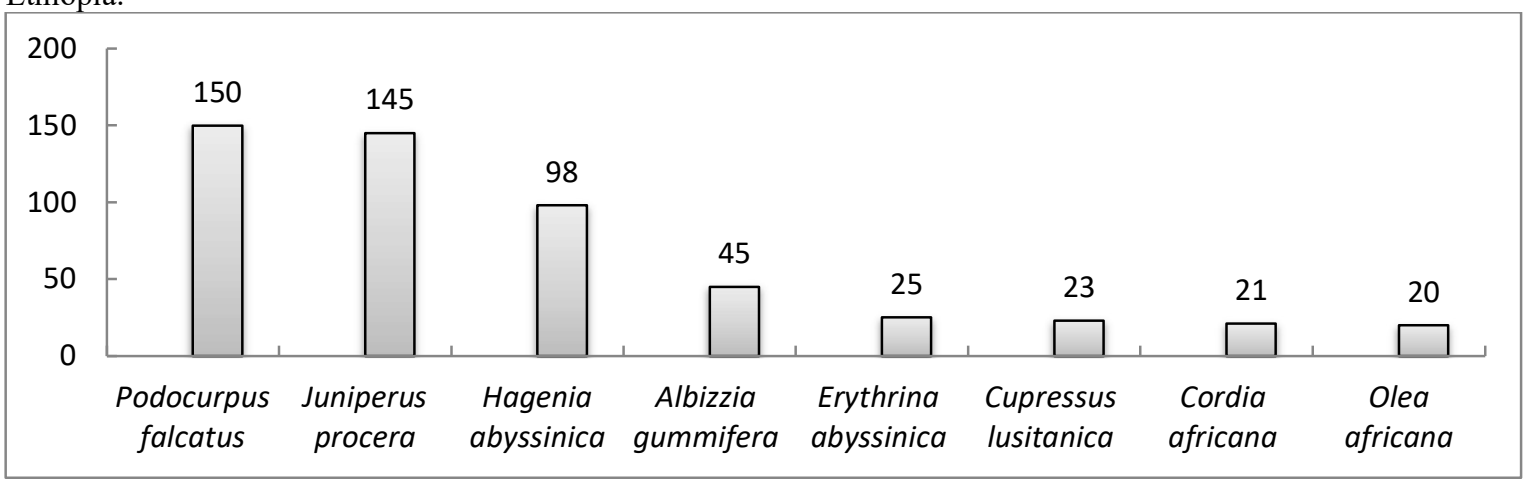

Figure 2. DBH of the top five species

Valuable information about the regeneration and/or recruitment status of the species as well as viability status of the population could be provided through examination of patterns of species population structures that could further be employed for devising evidence based conservation and management strategies (Abrham Abiyu et al., 2006).

\subsection{Basal area Class distribution}

The basal area in this study ranged from $10.9 \mathrm{~m}^{2} /$ ha for DBH class 1 to $59.02 \mathrm{~m}^{2} /$ ha for DBH class 11 (Figure 3). The total basal area was found to be $245.65 \mathrm{~m}^{2}$ of which about $67 \%$ were higher than DBH of $60 \mathrm{~cm}$. There was a J-shape curve relationship between DBH class and basal area class distribution (Figure 3). The presence of the larger basal area in the higher DBH class was due to the presence of trees with bigger diameter of older ages. The basal area showed a ' $\mathrm{J}$ ' shape distribution which is common for natural forests with active regeneration (Phillip 1983) and recruitment. Accordingly, active regeneration and recruitment in Jello-Muktar forest as portrayed in this study is a good sign of sustainability of the forest stock which has chances of insuring sustainable supply of 
products and services; and hence sustained livelihoods of the forest dependants. The presence of more active regeneration in this forest is related to the protection of the forest by Oromia Forest and wildlife Enterprise under Participatory Forest Management (PFM).

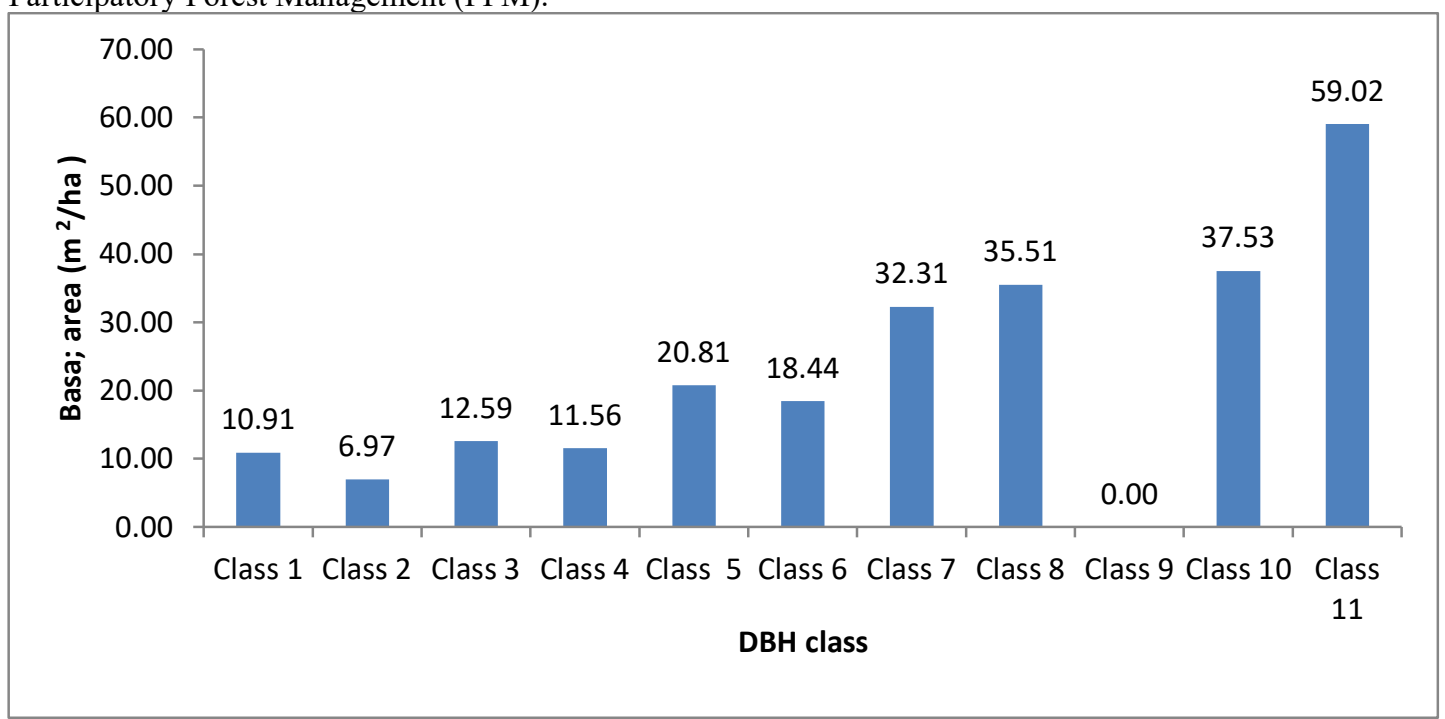

Figure 3. Basal area distribution across DBH class

The basal area of the last DBH class distributions from DBH class 7 to DBH class 11 comprises about $67 \%$ of the total basal area of the forest. The total basal area recorded in this study much higher than the total basal area/ha recorded for Asebot forest (Tura et al., 2017) and as well as higher than that reported for Boda dry evergreen Montane forest (Erenso et al., 2014). It is also by far higher than the range of basal area of 3.84-10.36 $\mathrm{m}^{2}$ /ha reported by Singh and Singh (1991) and 6.58-23.21 $\mathrm{m}^{2} /$ ha reported by Jha and Singh (1990) for several dry tropical communities in India. This may be related to the geographical differences of the two study areas. However it is lower when compared to the $882.23 \mathrm{~m}^{2} /$ ha basal area reported from Nechsar National Park (Shimelis et al., 2010).

It had been reported by several researchers that the relative importance of the species can be better provided by the measurement of basal area than simple stem count (Aliyi et al., 2015). Hence a given species can again be considered as the most important species in its habitat when it has largest contribution to the total basal area in that ecosystem/habitat (Ahmed et al., 2017).

The highest basal area in Jello-Muktar forest was contributed by some few species of Juniperus procesra followed by Podocurpus falcatus and Albizia gumifera (Figure 4). Similarly, the contribution of larger basal area by few species in the forest was reported for forests of Southwestern Ethiopia (Yeshitela and Bekele, 2003; Hundera and Gadissa,2008).

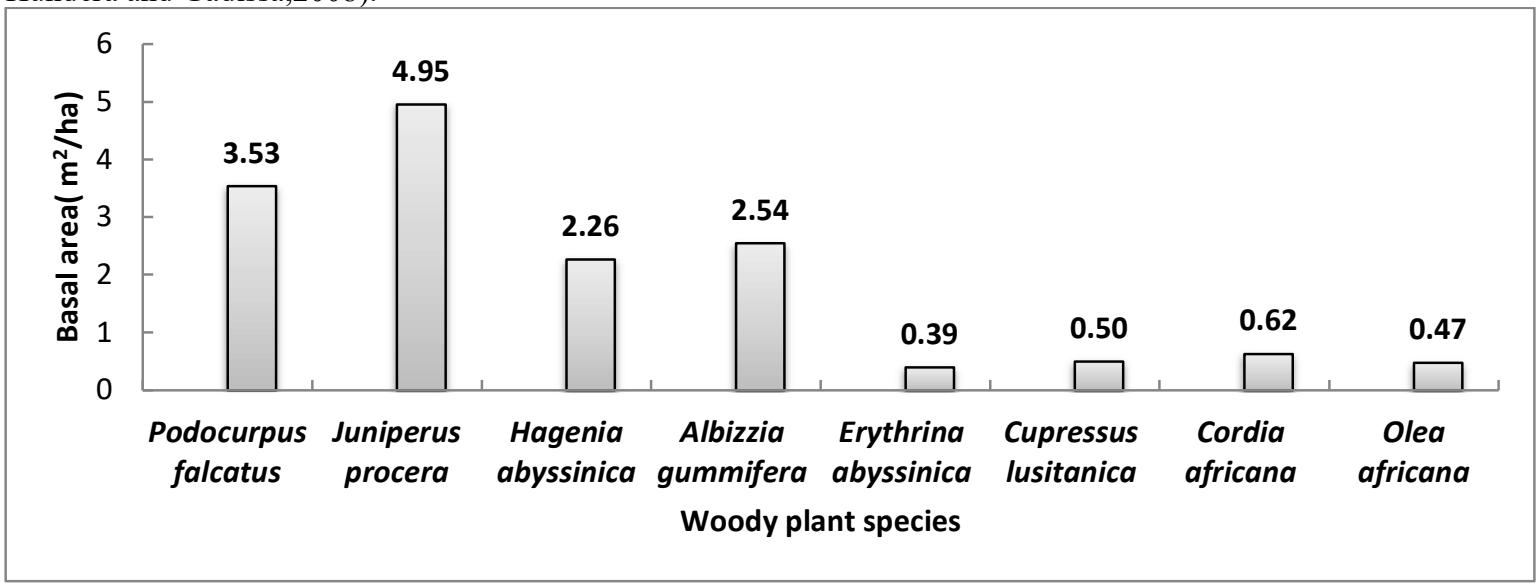

Figure 4. Basal area of the top eight species

The higher Basal areas of these species may also be due to the presence of adapted Root architecture to absorb nutrients for growth. This finding is similar to the work of Parthasarathy (2001) on changes in forest composition and structure working in three sites of a tropical forest. It had been reported that dominant species in terms of their 
basal areas can be seen as the most ecologically significant, and the most successful species in regeneration, pathogen resistance and/or the least preferred by animals (Mueller-Dombois and Ellenberg, 1974). Most of the shrub species recorded lower basal areas than those of tree species. Perhaps trees and shrubs with the lower basal area are attributed to their lower DBH. It could also be related to poor growth of tree species as result of poor root establishment for the acquisition of nutrients (Chauhan et al., 2008).

\subsection{Height class distributions}

The number of individual increased from 634 stems/ha in the first height class to 2335 stems/ha in height Class 2 . It then decreased from the second height class 2 with 2335 stems /ha to 203 stems /ha in the final height class 7 . The general trend in height class distribution in Jello-Muktar forest showed that higher proportion of woody plants was found in the lower height class (Figure 5) resulting in an inverted J-shape curve distribution pattern. About $10.8 \%$ of the individuals were found in the first height class $(1-5 \mathrm{~m})$. The second $(5.01-10 \mathrm{~m})$ and the third (10.01-15m) height classes accounted for $39.7 \%$ and $18.8 \%$ of the woody plant individuals respectively while the rest of the height classes (class 4 to class 7) comprised only $30.8 \%$ of the total individuals.

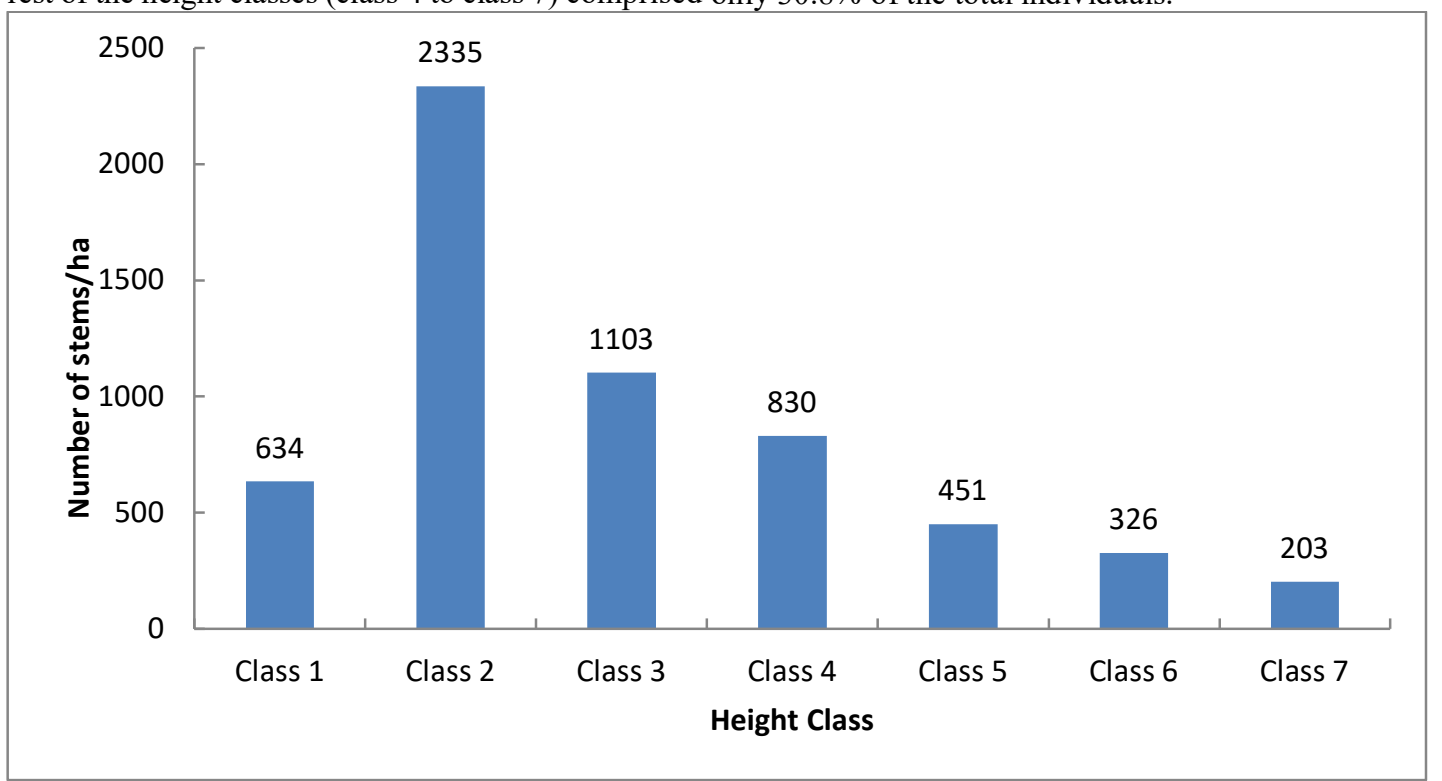

Figure 5. Distribution of density of individuals of woody plant species across the height class

In general there was trend of decreasing number of stems /ha with increasing height class. About $89 \%$ of trees and shrubs had heights of more than $5 \mathrm{~m}$ tall (Figure 5) but only $3.45 \%$ the total individuals recorded were found to have heights of more than $30 \mathrm{~m}$. The presence of less number of individual densities in the higher height classes agreed with Tura eat al. (2017). And this could be related to the high rate of selective logging as reported.

The height class distribution also showed a high rate of regeneration. The relationship between height class distribution and number of individuals showed an Inverted J-shape curve.

\section{CONCLUSION}

The population structure of the entire forest showed higher stem densities in the Lower diameter classes and progressively declining stem densities with increasing Diameter classes. Study of woody plant species population structure is an invaluable strategy for planning management actions and also helps in identifying the status of the forest stand with regard to its rate of disturbance. Hence it is better to manage those parts of forest stands with less number of individuals through enrichment planting of indigenous tree species.

\section{ACKNOWLEDGMENTS}

This work was funded by Oda Bultum University. We thank Oromia Forest and Wildlife enterprise of Hararghe branch for providing field logistics and basic information regarding the current and past history of the forest. We thank Mr. Husen Yusuf for assisting with field work. Thanks also go to Key informants and development agents particularly Mr. Mekonnen Worku for his guidance during field data collection.

\section{REFERENCES}

1. Giday, K. Management Interventions to Assist Restoration of Degraded Dry Afromontane Forest N. Ethiopia. Ph.D. Thesis, KU Leuven University, Leuven, Belgium, 2013 
2. F. K. Kalaba, C. H. Quinn, and A. J. Dougill. 2012. Contribution of forest provisioning ecosystem services to rural livelihoods in Copperbelt's Miombo woodlands, Zambia Sustainability Research Institute (SRI), vol. No. 41, School of Earth and Environment, The University of Leeds, Leeds, UK.

3. C. M. Ryan, M. Williams, and J. Grace. 1997. "Above- and belowground carbon stocks in a miombo woodland landscape of Mozambique," Biotropica, vol. 43, no. 4, pp. 423-432, 2011.

4. E. N. Chidumayo, Miombo Ecology and Management: An Introduction, IT Publications in Association with the Stockholm Environment Institute, London, UK.

5. Tura TT, Soromessa T, Leta S, Argaw M (2017) Plant Community Composition and Structure of Asabot Dry Afromontane Forest, West Harare Zone, Ethiopia. J Biodivers Endanger Species 5: 202. doi: 10.4172/23322543.1000202

6. Gurmessa F, Soromessa T, Kelbessa E. 2012. Structure and regeneration status of Kamto Afromontane moist forest, East Wollega Zone, west Ethiopia. J For Res 23: 205-216.

7. Hundera K, Gadissa T (2008) Woody species composition and structure of the Belete Forest, Jimma Zone, SW Ethiopia, Ethiopian journal of the Biological sciences 7: 1-15.

8. Yeshitela K, Bekele T(2003) The woody species composition and structure of Masha Anderacha forest, Southwestern Ethiopia. Ethiop J Biol Sci 2: 31-48.

9. Jha, C.S., and Singh, J.S., 1990. Composition and dynamics of dry ropical forest in relation to soil texture. Journal of Vegetation Science 1: 609-614.

10. Singh, L., and Singh, J.S., 1991. Species structure, dry matter dynamics and carbon flux of a dry tropical forest in India. Annals of Botany 68: 263-273.

11. Murphy, P.G., and Lugo, A.E., 1986. Ecology of tropical dry forest. Annual Review of Ecology and Systematics 17: 67-88.

12. Bormann, F. H. and Berlyn, G. P. 1981. Age and growth rate of tropical trees: New directions for research. School of Forestry Environmenital Studies, Yale University Bulletin No. 94.

13. Muller-Dombois, D. and Ellenberg, H. 1974. Aims and Methods of Vegetation Ecology. Wiley and Sons, New York, Pp. 547.

14. Kent, M. and Coker, P. 1992. Vegetation Description and Analysis. A practical approach. John Wiley and Sons, New York, Pp.363.

15. Juan J. Gaitan, Gabriel E. Oliva, Donaldo E. Bran, Fernando T. Maestre, Martin R. Aguiar, Esteban G. Jobbagy, Gustavo G. Buono, Daniela Ferrante, Viviana B. Nakamatsu, Georgina Ciari, Jorge M. Salomone and Virginia Massara. 2014. Vegetation structure is as important as climate for explaining ecosystem function across Patagonian rangelands. British Ecological Society, Journal of Ecology, 102, 1419-1428. doi: 10.1111/1365-2745.12273.

16. EMA (Ethiopian Mapping Agency).1999. Bedessa (Kuni), Ethiopian Topo Sheet 1:50,000. ETH-4, 0840 B2, EMA, Addis Ababa, Ethiopia.

17. Aliyi K, Hundera K, Dalle G (2015). Floristic composition, vegetation structure and regeneration status of Kimphe Lafa natural forest, Oromia Regional State, West Arsi, Ethiopia. Res. Rev..J. Life Sci. 5(1):19-32.

18. Ahmed Endris, Ali Seid and Addisu Asefa. 2017. Structure and regeneration status of woody plants in the Hallideghie wildlife reserve, North East Ethiopia. International Journal of Biodiversity and Conservation, Vol. 9(6), pp. 200-211. DOI: 10.5897/IJBC2017.1085.

19. Shimelse S, Bekele T, Mengistu A 2010. Floristic diversity and structure of Nechisar National Park, Ethiopia. J. Drylands 3(1):165180.

20. IBM Corporation (2001). IBM SPSS statistical software. IBM Corporation, Armonk, NY, USA.

21. Parthasarathy, N. 2001. Changes in forest composition and structure in three sites of tropical evergreen forest around Sengaltheri, Western Ghats. Current Science 80:389-393.

22. Chauhan DS, Dhanai CS, Bhupendra S, Chauhan S, Todaria NP, Coley PD, Barone JA 1996. Herbivory and plant defenses in tropical forests Ann. Rev. Ecol. Syst. 27:305-335.

23. Clemence Zimudzi and Christopher Chapano.2016. Diversity, Population Structure, and Above Ground Biomass in Woody Species on Ngomakurira Mountain, Domboshawa, Zimbabwe. International Journal of Biodiversity Volume 2016, Article ID 4909158, 11 pagehttp://dx.doi.org/10.1155/2016/4909158.

24. C.B.Virillo,F.R.Martins,J.Y.Tamashiro,andF.A.M.dos Santos. 2011. "Is size structure a good measure of future trends of plant populations? An empirical approach using five woody species from the cerrado (Brazilian savanna)," Acta Botanica Brasilica,vol.25,no.3,pp.593-600.

25. J. A. Isango. 2007. "Stand structure and tree species composition of Tanzania miombo woodlands: a case study from miombo woodlands of community-based forest management in Iringa District," in Proceedings of the 1 st MITMIOMBO Project Workshop,vol.50ofWorking Papers of the Finnish Forest Research Institute, pp. 43-56, Morogoro, Tanzania.

26. Haile Yineger, Ensermu Kelbessa, Tamrat Bekele and Ermias Lulekal. 2008. Floristic composition and structure of the dry afromontane forest at Bale mountains national park, Ethiopia. SINET: Ethiop. J. Sci., 
31(2):103-120.

27. Demel Teketay. 1997. Seedling populations and regeneration of woody species in dry Afromontane forests of Ethiopia. Forest Ecology and Management 98:149-165.

28. Abrham Abiyu, Vacik,H. and Glatzel,G2006. Population viability risk management applied to Boswellia papyfera (Del.) Hochst in Northeastern Ethiopia. Journal of the Drylands 1(2):98-107.

29. Fikadu Erenso, Melesse Maryo and Wendawek Abebe.2014. Floristic Compostion, Diversity and Vegetation Structure of woody plant communities in Boda dry evergreen Montane forest, West Shewa, Ethiopia. International Journal of Biodiversity and Conservation.Vol. 6(5), Pp382-391. DOI: 10. 5897//IJBC2014.0703. 